\title{
Pengembangan Video Senam Otak (Brain Gym) dalam Pembelajaran Bahasa Tunagrahita
}

\author{
Ary Puspita Ningrum, Sudarsini \\ Universitas Negeri Malang \\ Email: ningrump39@gmail.com
}

\begin{abstract}
Abstrak: Bahasa merupakan hal yang sangat dibutuhkan, khususnya menulis permulaan. Menulis permulaan memerlukan motorik halus yang memadai. Motorik halus pada anak tunagrahita mengalami gangguan sehingga memerlukan gerakan yang dapat mengkoordinasi motoriknya. Senam otak adalah gerakan sederhana yang dapat digunakan untuk melatih kognitif, motorik serta melemaskan otot-otot kecil jari-jari dan mengkoordinasi otak dengan bahu, lengan, dan mata. Tujuan penelitian ini adalah menghasilkan video senam otak. Video ini dikemas dalam bentuk CD yang diharapkan dapat membantu siswa untuk menulis permulaan Metode penelitian dan pengembangan yang digunakan dalam penelitian ini diadaptasi dari model Borg \& Gall. Hasil penelitian menunjukkan bahwa video senam otak (brain gym) layak dan efektif diterapkan bagi siswa tunagrahita setelah di validasi oleh ahli media, ahli senam otak dan ahli pembelajaran, serta pre test dan post test. Saran pemanfaatan penelitian ini adalah: (1)bagi siswa:peserta didik harus memperhatikan gerakan dan intruksi dari guru, (2) bagi guru: Memperhatikan kesulitan peserta didik dalam bergerak, khususnya menggerakkan tangan.
\end{abstract}

Kata Kunci: Senam Otak (Brain Gym); Bahasa (menulis permulaan); Tunagrahita

\begin{abstract}
Language is a very necessary thing, especially in writing the beginning. Beginning the writing requires a fine motor ability wich adequate. The fine motor in the students with intellectual disability is impaired so requiring movement that can coordinate motoric. Brain gym is a simple movement that can be used to train cognitive, motor and flexibility the small muscles of the fingers and coordinates the brain with the shoulders, arms, and eyes. The purpose of this research is to produce brain gymnastics. This video is packaged in $\mathrm{CD}$ format which is expected to help students to write the beginning. The research and development method that used in this research was adapted from the Borg \& Gall model. The results showed that the brain gym was feasible and effective was applied for the intellectual disability after validation by media experts, brain gym experts and learning experts, as well as pre test and post test. Untilization suggestions of this research are: (1) for students: students should pay attention to teacher's movement and instruction, (2) for teacher: pay attention to student's difficulty in moving, especially hand moving.
\end{abstract}

Keywords: Brain Gym; Language; Intellectual Dissability

Bahasa merupakan alat komunikasi antara manusia yang dapat menjadi tempat menuangkan ide dalam pikiran. Pembelajaran bahasa ada 3 macam yaitu : membaca, menulis dan berhitung. Dalam hal ini peneliti hanya meneliti tentang menulis permulaan. Menulis merupakan salah satu aspek terpenting dalam proses pembelajaran. Menulis tidak hanya sekedar membuat coretan dengan tangan ataupun menyalin bentuk tulisan, namun dengan menulis seseorang dapat mengekspresikan apa yang sedang mereka alami. Menulis adalah suatu alat yang sangat ampuh dalam belajar yang dengan sendirinya memainkan peran yang sangat penting dalam bidang pendidikan (Kusumaningtias, et al (2013). Menulis permulaan di SLB sendiri pada dasarnya ditekankan untuk mempermudah siswa dalam mengikuti pembelajaran menulis, seperti membiasakan anak untuk menggabungkan titik yang akan membentuk huruf, serta sejauh mana anak mampu menebalkan, menirukan garis, angka dan huruf. Menurut Muchlisoh et al (dalam Pandu, 2012), bahwa menulis permulaan adalah jenis menulis yang diajarkan kepada kelas 1 dan 2 SD. Disebut demikian karena dalam menulis permulaan lebih diutamakan pengenalan penulisan huruf dan kedudukan atau fungsingnya di dalam kata dan kalimat. Menulis merupakan aktivitas yang kompleks, yang mengharuskan untuk mengintegrasi gerakan lengan, tangan, jari dan mata, sehingga memungkinkan anak dapat menulis dengan baik. Menurut pengertian diatas dapat disimpulkan bahwa menulis permulaan merupakan aktivitas yang sangat komples, yang harus mengordinasikan antara otak dan tangan serta jari-jari. Kemampuan menulis permulaan ditekankan pada kemampuan anak untuk menghubungkan titik-titik, garis serta grafik sehingga akan menjadi simbol huruf maupun abjad yang dapat dipahami oleh penulis maupun pembaca.

Menulis permulaan ini sangat diperlukan adanya koordinasi indra yang baik serta keterampilanketerampilan dasar dalam menulis. Seperti, menggerakkan tangan, dan membuat coretan yang baik. Keberhasilan menulis sendiri dipengaruhi oleh kemampuan kognitif dan motorik halus serta koordinasi indra. Menurut Gunadi (dalam Aistiyanti, 2015) terdapat 9 pernyataan dalam belajar menulis diantaranya: kesiapan perkembangan, keseimbangan kestabilan bahu, kontrol lengan bawah, kestabilan lengan bawah, kestabilan pergelangan tangan, graps, 
bilateral handuse, sensory experiences and eye, hand, and arm coordination. Kekakuan otot pada anak dapat dilatih dengan cara melatih otot-otot anak dengan gerakan yang memungkinkan anak dapat melemaskan kekakuan di otot anak. Berbagai jenis kegiatan fisik yang memungkinkan dilakukan seperti aerobik, anaerobik dsb. Salah satu yang dapat digunakan adalah senam otak (brain gym) yang diciptakan oleh Paul Dennison pada tahun 70-an. Program brain gym (senam otak) ini telah banyak membantu anak yang mengalami gangguan perkembangan maupun berkesulitan belajar (Nidiarto, 2007). Senam otak (brain gym) merupakan latihan yang terangkai dari gerakan-gerakan dinamis yang melibatkan keseimbangan otak kiri dan otak kanan secara bersamaan. Gerakan pada brain gym ini memungkinkan siswa untuk melatih kelenturan tangan, dan jari-jarinya melalui stimulus dari otak. Senam otak menekankan pada gerakan tubuh untuk menyelaraskan fungsi otak. Kemampuan menulis sendiri dikendalikan melalui otak kiri dan otak kanan berfungsi sebagai pengenalan bentuk dan ruang. Senam otak adalah metode stimulasi otak yang dapat mengaktifkan otak pada 3 dimensi yaitu literalitas, pemfokusan dan pemusatan pengaturan otak.

Muhammad, (dalam Diana, 2017) mengungkapkan tiga mekanisme kerja brain gym diantaranya : (a) Dimensi lateralis (untuk belahan otak kanan dan kiri), tujuan dari dimensi ini sendiri adalah untuk mengoptimalkan kemampuan belajar anak. Sedangkan gerakan dalam dimensi ini untuk meningkatkan aktivitas mendengar, melihat, menulis dan bergerak. (b) Dimensi pemfokusan (bagian belakang otak atau batang otak) dan bagian depan otak. Dimensi ini dapat membantu kesiapan dan konsentrasi untuk menerima sesuatu yang baru serta mengekspresikan apa saja yang sudah diketahui anak. (c) Dimensi pemusatan (untuk sistem limbic) dan otak besar. Dimensi ini dapat membantu meningkatkan energi yang menyagkut berjalan, mengorganisasi dan tes. Adapun manfaatnya adalah untuk membantu mengontrol emosi. Gerakan senam otak (brain gym) dapat membantu anak tunagrahita untuk menjalankan kegiatan sensori dan motoriknya. Anak tunagrahita mengalami hambatan dalam motorik halusnya. Sehingga dengan gerakan dari senam otak ini, anak tunagrahita akan mampu melatih motorik halusnya melalui stimulus yang dilakukan oleh senam otak (brain gym). Gerakan brain gym sangat berguna untuk mengaktifkan bagian dalam otak khusunya area yang berperan dalam bahasa. Tunagrahita adalah anak yang memiliki tingkat intelegensi di bawah anak normal pada umumnya. Efendi, (2006) menyatakan bahwa seseorang dikategorikan berkelainan mental subnormal atau tunagrahita, jika ia memiliki tingkat kecerdasan yang sedemikian rendahnya. Sehingga dalam proses perkembangannya memerlukan bantuan dan layanan secara spesifik termasuk dalam hal pendidikannya.

Anak tunagrahita sendiri mengalami keterbatasan, dimana salah satu dari keterbatasan itu adalah kesulitan dalam belajar di sekolahan terutama dalam hal bahasa (membaca, menulis dan berhitung).

Berdasarkan observasi yang dilakukan di SDLB Kemala Bhayangkari Trenggalek peneliti menemukan anak mengalami kesulitan dalam membedakan simbol huruf, mereka cenderung mangalami kesulitan dalam membedakan huruf a, o, e, p, d, b, s dan k serta pergerakan tangan siswa masih sulit dan kaku sehingga ketika menebalkan titik-titik serta menarik garis hasilnya tidak rapi dan berantakan. Dari masalah tersebut, penulis ingin mengetahui sejauh mana anak tunagrahita dapat menulis permulaan dengan diberikannya stimulus berupa pengembangan video senam otak.

Seperti penelitian terdahulu yang dilakukan oleh Elisa (2016) berjudul "Penggunaan Senam Otak (Brain Gym) Untuk Meningkatkan Kemampuan Menulis Permulaan Bagi Anak Tunagrahita Ringan Kelas D IV Di SDLB Al Azhar Bukit Tinggi" menemukan bahwa kemampuan menulis anak tunagrahita meningkat dnegan menggunakan senam otak (brain gym).

\section{METODE}

Berdasarkan pada tujuan penelitian dan pengembangan ini yaitu menghasilkan media pembelajaran video yang mempermudah siswa dalam mengaktifkan sistem koordinasi (otak, tangan, mata dan jari-jari) agar dapat membantu siswa untuk berbahasa (menulis) permulaan. Pemilihan model pengembangan ini menggunakan model pengembangan research \& development (R\&D) dari Borg and Gall (dalam Hasyim, 2016). Menurut Sugiono (2016) metode R \& D adalah metode penelitian yang digunakan untuk menghasilkan produk tertentu, dan menguji keefektifan produk tersebut. Menurut Sukmadinata (dalam fauziah, 2017) penelitian dan pengembangan ialah proses atau tahapan-tahapan untuk membuat sesuatu produk baru atau menyempurnakan produk yang telah ada yang dapat dipertanggungjawabkan. Penelitian dan pengembangan bertujuan untuk mengembangkan, menguji kemanfaatan dan efektivitas produk yang dikembangkan dalam Hasyim (2016).

Berikut ini merupakan langkah-langkah rancangan dari Borg and Gall : (1) penelitian dan pengumpulan informasi, (2) perencanaan, (3) pengembangan produk, (4) uji coba awal, (5) revisi produk, (6) uji coba lapangan, (7) revisi produk uji coba lapangan, (8) uji coba operasional produk, (9) revisi produk, dan (10) implementasi dan desiminasi.

Peneliti menggunakan 7 langkah dari 10 langkah model pengambangan reasearch and development (R\&D) dari Borg and Gall. Pemilihan 7 langkah tersebut telah mempertimbangkan karakteristik yang akan diteliti dan keterbatasan waktu, tenaga serta biaya yang dimiliki peneliti. 
Tabel 1. Hasil Uji Coba Pre-test

\begin{tabular}{llllll}
\hline No & Nama & $\begin{array}{l}\text { Skor yang } \\
\text { diperoleh }\end{array}$ & $\begin{array}{l}\text { Skor } \\
\text { maksimal }\end{array}$ & Konstanta & $\begin{array}{l}\text { Total } \\
\text { nilai }\end{array}$ \\
\hline 1 & 1 & 13 & 20 & 100 & 65 \\
2 & 2 & 9 & 20 & 100 & 45 \\
3 & 3 & 9 & 20 & 100 & 45 \\
4 & 4 & 9 & 20 & 100 & 45 \\
5 & 5 & 16 & 20 & 100 & 80 \\
6 & 6 & 16 & 20 & 100 & 80 \\
\hline \multicolumn{5}{l}{ Total Skor } & 360 \\
\hline \multicolumn{5}{l}{ Rata - rata } \\
\hline
\end{tabular}

Tabel 2. Hasil Uji Coba Post-test

\begin{tabular}{llllll}
\hline No & Nama & $\begin{array}{l}\text { Skor yang } \\
\text { diperoleh }\end{array}$ & $\begin{array}{l}\text { Skor } \\
\text { maksimal }\end{array}$ & konstanta & $\begin{array}{l}\text { Total } \\
\text { nilai }\end{array}$ \\
\hline 1 & 1 & 17 & 20 & 100 & 85 \\
2 & 2 & 15 & 20 & 100 & 75 \\
3 & 3 & 15 & 20 & 100 & 75 \\
4 & 4 & 15 & 20 & 100 & 75 \\
5 & 5 & 19 & 20 & 100 & 95 \\
6 & 6 & 19 & 20 & 100 & 95 \\
\hline \multicolumn{7}{l}{ Total Skor } \\
\hline \multicolumn{5}{l}{ Rata - rata } \\
\hline
\end{tabular}

Seperti yang diungkapkan oleh Gooch dalam Hasyim (2016) sebagai berikut : (1) penelitian dan pengumpulan data; (2) perencanaan; (3) pengembangan desain produk awal; (4) validasi produk awal; (5) revisi produk awal; (5) uji coba lapangan dan (7) revisi produk akhir. Langkah-langkah 1 sampai 7 model pengembangan Research and Development (R\&D) sebagai berikut: (1) Melakukan penelitian dan pengumpulan data informasi termasuk kajian pustaka dan analisis kebutuhan, (2) Perencanaan produk, (3) Mengembangkan bentuk produk awal (peneliti membuat produk berupa variasi senam otak (brain gym) untuk pembelajaran bahasa yang dikhususkan untuk pembelajaran menulis permulaan anka, mulai dari tahap awal sampai implementasi yang dikemas dalam sebuah audio visual, (4) Proses validasi yang diberikan oleh ahli, (5) Revisi produk dari hasil evaluasi ahli yang digunakan untuk perbaikan terhadap produk awal yang dibuat peneliti, (6) Uji kelompok dengan menggunakan 7 siswa tunagrahita, (7) Revisi produk akhir yang dilakukan berdasarkan uji lapangan dan menghasilkan produk variasi latihan senam otak dalam sebuat video latihan atau audio visual.

Uji coba produk dalam penelitian ini di samping untuk mendapatkan saran dari para ahli demi perbaikan atau kesempurnaan produk ini juga digunakan untuk pengumpulan data sebagai dasar untuk menetapkan tingkat kelayakan produk yang dihasilkan. Pada bagian ini terdapat beberapa yang aspek yang dikemukakan yaitu : desain uji coba, subjek uji coba, jenis data, instrumen pengumpulan data dan teknik analisis data. Desain uji coba dilakukan dengan 2 tahapan, diantaranya evaluasi ahli dan uji coba siswa. (a) evaluasi ahli diambil dengan menggunakan angket oleh 3 ahli yaitu 1 ahli media, 1 ahli materi I (senam otak) dan 1 ahli materi 2 (guru kelas). (b) uji coba siswa dilakukan kepada 7 siswa SDLB Kemala Bhayangkari Trenggalek. Subjek uji coba yang terlibat dalam penelitian dan pengembangan ini adalah: (a) subjek evaluasi terdiri dari 1 ahli media, 1 ahli materi I (senam otak) dan 1 ahli materi 2 (guru kelas). (b) subjek uji coba siswa dilakukan kepada 7 siswa SDLB Kemala Bhayangkari Trenggalek. Jenis data yang diperoleh merupakan data kuantitatif dan kualitatif. Data kuantitatif adalah data yang berbentuk angka, yang di peroleh melalui angket yang dibagikan kepada para ahli, yaitu ahli media, ahli senam otak, ahli pembelajaran ABK. Data kualitatif diperoleh dari observasi, wawancara dan angket yang berisi (saran dan kritikan dari ahli). Instrumen yang digunakan dalam penelitian dan pengembangan ini berupa: (a) angket validasi, (b) test hasil belajar, (c) wawancara dan (d) observasi. Teknik analisis data menggunakan analisis data kualitatif dan kuantitatif. Teknik analisis data yang digunakan dalam penelitian ini adalah kualitatif dan kuantitatif. Data kualitatif berupa hasil observasi, wawancara dan angket (saran dan kritikan) dari para ahli. Sedangkan data kuantitatif diperoleh dari kuesioner yang telah diisi oleh para ahli.

\section{HASIL DAN PEMBAHASAN}

\section{Hasil}

Berdasarkan hasil data pertama validasi ahli media pada tabel 1, maka dilakukan perhitungan presentase kelayakan media sebagai berikut dan memperoleh hasil sehingga dapat dinyatakan sangat layak dan sangat valid untuk digunakan dalam pembelajaran. Adapun saran perbaikan yang diberikan ahli media adalah (1) lighting video perlu dicerahkan, (2) beri petunjuk pemanfaatan dan (3) beri spesifikasi produk pada cover CD atau DVD. Kedua validasi ahli materi 1 pada tabel 1, maka dilakukan perhitungan presentase kelayakan media sebagai berikut dan memperoleh hasil sehingga dapat dinyatakan sangat layak dan sangat valid untuk digunakan dalam pembelajaran. Adapun saran perbaikan yang diberikan ahli materi 1 (senam otak) adalah gerakan antara tangan kanan dan kiri harus seimbang pada saat menulis, sehingga usahakan melakukan gerakan menulis menggunakan tangan kanan dan kiri secara bergantian. Ketiga validasi ahli materi 2, maka dilakukan perhitungan presentase kelayakan media sebagai berikut dan memperoleh hasil sehingga dapat dinyatakan sangat layak dan sangat valid untuk digunakan dalam pembelajaran. Adapun saran perbaikan yang diberikan ahli materi 2 adalah tampilan video dibuat lebih menarik. 
Data uji coba produk di lapangan diperoleh dari pre test dan post test kepada 6 siswa. Praktik menulis permulaan ini terdiri dari 5 item penilaian yang meliputi; menebali dan menarik titik, Membuat bangun datar (persegi, segitiga, lingkaran), Kejelasan menulis huruf, membedakan huruf, dan keaktifan tangan.

Nilai rata-rata pre-test seluruh peserta didik adalah 60 yang berarti kemampuan anak dalam menulis permulaan dalam tingkat sedang, sedangkan nilai posttest seluruh peserta didik adalah 83,33 mempunyai arti bahwa tingkat menulis permulaan anak dikategorikan dalam kategori tinggi. Kesimpulan yang diperoleh adalah "skor pre-test lebih kecil daripada post-test', atau dengan kata lain "skor pre-test mengalami kenaikan sehingga media "video Senam Otak (Brain Gym) yang dikembangkan merupakan media yang efektif karena hasil uji cobanya mendapatkan peningkatan nilai.

\section{Pembahasan}

Produk yang dikembangkan oleh peneliti merupakan senam otak (brain gym) untuk melatih menulis permulaan pada tunagrahita, produk ini memiliki keunggulan gerakan yang sudah disesuaiakan dengan karakteristik anak tunagrahita serta terdapat beberapa implementasi yang memudahkan anak untuk melatih koordinasi tangan, jari, bahu, mata dan otak. Menurut Lestari dalam Sawitri (2017) mengatakan modal utama dalam menulis permulaan adalah keterampilan menggunakan tangan dan jari-jari. Anak tunagrahita sendiri mengalami kesulitan untuk mengaktifkan tangan dan otaknya sehingga mereka mengalami kesulitan dalam melakukan menulis permulaan. Selain itu dalam menulis permulaan perlu adanya kemampuan kognitif serta kemampuan motorik yang memadai. Seperti yang dikemukakan oleh Tomo (dalam Aristiyanti, 2015), "menulis merupakan kegiatan yang membutuhkan keterampilan motorik halus bagian tangan yang akan melibatkan banyak otot kecil pada jari, telapak tangan dan pergelangan tangan".

Senam otak (brain gym) memiliki gerakan-gerakan yang dapat mengaktifkan dan membantu fungsi otak sehingga dapat mengordinasikan otak dengan mata, tangan, jari sehingga anak dapat mengaktifkan otototot yang kekakuan. Aristiyanti (2015) menyatakan bahwa senam otak dapat dilakukan untuk melatih fungsi kognitif dan motorik. Senam otak yang dikembangkangkan dalam menulis permulaan adalah (1) angka 8 tidur (Lazy Eight's), Abjad 8 (Alphabet Eight's), Mengaktifkan tangan (Arm Activation) dan coretan ganda. Selain itu ada beberapa implementasi yaitu menggabungkan titik titik menggunakan tangan kanan dan kiri, menggambar lingkaran, segitiga, dan persegi. Menurut Yanuarita (2013), “dari segi fungsi otak terdiri dari dua belahan yang memiliki tiga dimensi yang saling berhubungan". Maka, apabila dapat menggunakan keseluruhan otak tersebut fungsi otak juga akan optimal. Begitu pula dengan anak tunagrahita yang memiliki kemampuan kognitif dan motorik yang rendah, menyebabkan mereka mnegalami hambatan dalam proses pembelajaran, terutama dalam aspek menulis permulaan.

Media pembelajaran disekolah sangat bermacam bentuknya, salah satunya adalah video. Media audio visual adalah media yang melibatkan indera pendengaran danpenglihatan dalm satu proses. Gagne' dan Briggs (dalam Arsyad, 2013) secara implisit mengatakan bahwa media pembelajaran meliputi alat yang secara fisik dapat membatu penyampaian materi yang terdiri dari, buku, tipe recorderfilm, slide, video dan kaset. Media pembelajaran dikatakan berhasil apabila dapat memberikan stimulus yang baik kepada peserta didik ketik pembelajaran sedang berlangsung. Dalam pengembangan ini telah dilakukan analisis kebutuhan di SDLB Kemala Bhayangkari 1 Trenggalek kelas II dengan wawancara guru dan observasi selama proses pembelajaran. Selama proses pembuatan "Video Senam Otak (Brain Gym)" ini tidak terlepas dari penilaian dan saran para ahli yaitu: ahli materi 1 , ahli materi 2 serta ahli media. Saran dan masukan dari para ahli dijadikan untuk menyempurnakan produk.

Pembuatan produk pengembangan senam otak (brain gym) untuk melatih menulis permulaan anak tunagrahita di SDLB Kemala Bhayangkari Trenggalek dimungkinkan adanya kesalahan dan kekurangan. Maka dari itu produk yang dikembangkan mulai dari rancangan produk hingga produk ini terselesaikan masih memerlukan beberapa revisi untuk mendapatkan produk yang masksimal. Sebagai upaya untuk memaksimalkan produk yang dikembangkan dalam pembuatan produk ini memerlukan evaluasi dari beberapa ahli, yaitu ahli media, ahli materi 1 (senam otak) dan ahli materi 2 (guru kelas) serta melakukan uji coba. Setelah diadakan revisi terhadap media, maka proses selanjutnya adalah uji coba yang dilaksanakan di SLDLB Kemala Bhayangkari Trenggalek melalui pre-test dan post test.

Penelitian ini dikaitkan dengan penelitian yang dilakukan oleh Elisa (2016) yang berjudul “ Penggunaan Senam Otak (Brain Gym) Untuk Meningkatkan Kemampuan Menulis Permulaan Bagi Anak Tunagrahita Ringan Kelas D IV Di SDLB Al Azhar Bukittinggi" menemukan bahwa kemampuan menulis anak tunagrahita meningkat dengan menggunakan senam otak (brain gym). Hal ini membuktikan bahwa : senam otak (brain gym) dapat membantu anak dalam berbahasa (membaca, menulis, dan berhitung). Dibuktikan lagi oleh Pranata, Sony Abdian yang berjudul pengaruh abjad 8 (alphabet $8 s$ ) dalam mnegatasi kesulitan menulis (dysgraphia) dan membaca (dyslexia) anak tunagrahita ringan yang memberikan hasil bahwa abjad 8 (alphabhet 
$8 s$ ) berpengaruh positif dalam mengatasi kesulitan membaca dan menulis anak tunagrahita ringankelas VI SDLBC Setya Dharma Surakarta.

Perbedaan dengan para peneliti terdahulu, penelitian ini mencakup beberapa gerakan brain gym seperti (1) angka 8 tidur (Lazy Eight's) yang berguna untuk membedakan dan menghafalkan simbol huruf, (2) abjad 8 (alphabet Eight's) yang bermanfaat untuk menunjang koordinasi mata dan tangan serta menghafal dan membedakan simbol huruf,(3) mengaktifkan tangan (arm action) yang bermanfaat unyuk mengaktifkan tangan dalam membantu menulis serta membuat bahu lebih relaks, dan (4) coretan ganda yang bermanfaat untuk memudahkan menulis dan merileksasikan mata yang memberikan respon kepada aktivitas otak anak. Selain itu, terdapat juga implementasi di dalam video senam otak jadi menambah nilai tepat guna bagi siswa.

kelebihan dari produk ini adalah (1) mudah untuk dioperasikan, (2) tidak membutuhkan waktu yang lama dalam penggunaanya, (3) dilengkapi dengan buku panduan pemanfaatannya, (4) tampilan dan isi video di sesuaikan dengan kondisi anak serta kebutuhan peserta didik di sekolah dan (5) video ini dilengkapi implementasi dengan menggunakan tangan kanan dan tangkan kiri. Kekurangannya adalah media ini hanya terbatas bisa digunakan saat ada laptop/komputer.

\section{KESIMPULAN DAN SARAN}

\section{Kesimpulan}

Hasil penelitian dan pengembangan dapat disimpulkan sebagai berikut: (1) berdasarkan hasil dan evaluasi para ahli bahwa produk Pengembangan Video Senam Otak (Brain Gym) Dalam Pembelajaran Bahasa Tunagrahita Di SDLB Kemala Bhayangkari Trenggalek dinyatakan memili kemenarikan, kemudahan dan sesuai dengan karakteristik anak tunagrahita untuk melatih menulis permulaan serta sesuai dnegan materi yang sedang diajarkan, (2) berdasarkan hasil evaluasi uji produk dapat disimpulkan bahwa produk Pengembangan Video Senam Otak (Brain Gym) Dalam Pembelajaran Bahasa Tunagrahita Di SDLB Kemala Bhayangkari Trenggalek dinyatakan memiliki kemenarikan dan kegunaan media jelas dalam melatih anak untuk mengaktifkan motoriknya sehingga dapat melatih menulis permulaan.

\section{Saran}

Adapun saran yamg akan dijabarkan oleh penulis adalah sebagai berikut : (a) saran bagi peserta didik dalam video ini adalah peserta didik harus memperhatikan gerakan dan intruksi dari guru, (b) Sebelum memanfatakan "Video Senam Otak (Brain Gym)" demi kelancaran proses pembelajaran sebaiknya guru menguasaik beberapa teknik, menyiapkan peralatan yang mendukung seperti, komputer atau laptop, LCD, speaker dan peralatan listrik lainnya, membaca dengan cermat buku panduan yang telah disediakan, memperhatikan kesulitan peserta didik dalam bergerak, khususnya menggerakkan tangan, (c) untuk pengembang lain yang menginginkan membuat topik pengembangan yang sama dengan produk media video ini disarankan untuk mengkaji lebih dalam tentang pemilihan gerakan dan implementasi, serta pemilihan format video yang akan digunakan harus disesuaikan dnegan karakteristik materi. Diharapkan juga akan ada penelitian pengembangan lebih lanjut tentang melatik kemampuan menulis permulaan khususnya melalui penggunaan senam otak, penelitian eksperimen untuk mengetahui keefektifan penggunaan video senam otak di dalam kelas.

\section{DAFTAR RUJUKAN}

Afandi, A. 2013. Pengembangan Video Pembelajaran Senam Otak (Brain Gym) Berbasis Tematik di TK SBI Tlogowaru Kota Malang. Universitas Negeri Malang : PG Paud.

Akbar, S. (2016). Instrumen Perangkat Pembelajaran. Bandung : PT Remaja Rosdakarya Offset.

Arikunto, S. (2012). Dasar -Dasar Evaluasi Pendidikan. Jakarta : Bumi Aksara

Aristiyani, C. 2015. Pengaruh Senam Otak Arm Activation (Mengaktifkan Tangan) Terhadap Kemampuan Menulis Permulaan Pada Anak Autistik Kelas VI Di Sekolah Luar Biasa Autisma Dian Amanah Yogyakarta (Doctoral Dissertation, Fakultas Ilmu Pendidikan).

Arsyad, A. (2013). Media Pembelajaran. Edisi revisi. Jakarta: PT. Grafindo Persada.

Dennison, P E \& Gail E. D. (2002). Brain Gym (Senam Otak). Jakarta : Grasindo.

Diana S; Ferilia A; dan Elyana M. 2017 . Brain Gym Stimulasi perkembangan Anak. Paud 1. Surakrta: CV Kerata Group.

Dryden, G \& Dr. Jeannette V. (2003). Revolution Cara Belajar (The Learning Revolution). Bandung: Kaifa.

Efendi, M. (2006). Pengantar Psikopedagogik Anak Berkelainan. Jakarta: PT Bumi Aksara

Elisa, A. (2016). Penggunaan Senam Otak (Brain Gym) Untuk Meningkatkan Kemampuan Menulis Bagi Anak Tunagrahita Ringan Kelas V Di SLB Al Azhar Bukittinggi. Univeristas Negeri Padang. Pendidikan Luar Biasa. Jurnal Ilmiah Pendidikan Khusus

Hasyim, A. 2016. Metode Penelitian Dan Pengembangan Di Sekolah. Yogyakarta:media kadami 
Pranata, S. (2011). Pengaruh Abjad 8 (Alphabets 8s) Dalam Mengatasi Kesulitan Menulis (Dysgraphia) Dan Membaca (Dyslexia) Anak Tunagrahita Ringan. Surakarta: Universitas Sebelas Maret. (online) digilip.uns.ac.id

Kusumaningsih, D dkk. (2013). Terampil Berbahasa Indonesia. Yogyakarta : CV Andi.

Razak, A. 2014. Meningkatkan Kemampuan Membaca Permulaan Bagi Anak Kesulitan Belajar Melalui Brain Gym. Jurnal Ilmiah Pendidikan Khusus. Vol. 3 (1). Hal:234-244

Sawitri, D. A. 2017. Pengaruh Finger Painting Terhadap Kemampuan Menulis Permulaan Pada Siswa Tunagrahita Ringan di SLB BC Kepanjen Malang. SKRIPSI, Jurusan Pendidikan Luar Biasa-Fakultas Ilmu Pendidikan UM.
Sugiyono. 2016. Metode Penelitian Kuantitatif, Kualitatif,Dan $R \&$ D. Bandung : Alfabeta

Sugiyono. 2016. Metodelogi Penelitian Pendidikan. Bandung : Alfabeta

Wibisono, L. (2012). Kemampuan Menulis Permulaan Anak Tunagrahita Sedang Kelas 2 SDLB Insan Mandiri Dlingo. Universitas Yogyakarta : Pendidikan Luar Biasa. (online) 